\title{
MODULATORY ROLE OF ANTIOXIDANT VITAMINS C AND E ON ERYTHROCYTE OSMOTIC FRAGILITY INDUCED BY CHRONIC SODIUM NITRATE ADMINISTRATION IN RATS
}

\author{
${ }^{* 1}$ Yarube, I. U. and ${ }^{2}$ Ayo, J.O. \\ ${ }^{1}$ Department of Human Physiology, Faculty of Medicine, Bayero University, Kano. \\ ${ }^{2}$ Department of Physiology and Pharmacology, Faculty of Veterinary Medicine, Ahmadu Bello \\ University, Zaria. \\ *Correspondence author: dryarube@yahoo.com
}

\begin{abstract}
Vitamin $C$ and $E$ supplements were administered to sodium nitrate-treated rats in order to examine the possible ameliorative effects of these antioxidants on erythrocyte osmotic fragility. Seventy adult Wistar rats were randomly divided into seven groups $(n=10)$ and administered drugs or distilled water orally using a metallic canular for 60 days. Group I (control) received distilled water; Group II - $30 \mathrm{mg} / \mathrm{kg} \mathrm{NaNO}$; Group III - $30 \mathrm{mg} / \mathrm{kg} \mathrm{NaNO}{ }_{3}+500 \mathrm{mg} / \mathrm{kg}$ vitamin C; Group IV - 30 $\mathrm{mg} / \mathrm{kg} \mathrm{NaNO}{ }_{3}+750 \mathrm{mg} / \mathrm{kg}$ vitamin C; Group V-30 mg/kg NaNO $\mathrm{O}_{3}+300 \mathrm{mg} / \mathrm{kg}$ vitamin E; Group $V I-30 \mathrm{mg} / \mathrm{kg} \mathrm{NaNO}{ }_{3}+400 \mathrm{mg} / \mathrm{kg}$ vitamin E; Group VII - $30 \mathrm{mg} / \mathrm{kg} \mathrm{NaNO} \mathrm{N}_{3}+500 \mathrm{mg} / \mathrm{kg}$ vitamin $C+300 \mathrm{mg} / \mathrm{kg}$ vitamin E. Blood was collected from each animal at the end of the experiment to determine erythrocyte osmotic fragility. The results showed that, sodium nitrate caused significant decrease in erythrocyte osmotic fragility. Each of the vitamin administered separately increased erythrocyte osmotic fragility back to normal values. However, co-administration of the two vitamins very significantly increased erythrocyte osmotic fragility to above normal values. It was concluded that, vitamin $C$ and $E$ administered separately ameliorated sodium nitrate toxicity in a dose dependant manner. Co-administration of the two vitamins showed synergistic effect which was detrimental to the rats due to the risk of anaemia.
\end{abstract}

Keywords: antioxidants, vitamin C, vitamin E, sodium nitrate, erythrocytes, osmotic fragility, rats.

\section{INTRODUCTION}

Nitrogenous fertilizers used in agriculture contain different nitrate salts which are passed from the soil to different fruits and vegetables as well as ground and surface water which are eventually consumed by man (Manassaram et al., 2006). Nitrates are also used in the industry for preservation (Wogan et al., 1995) and coloring of tinned meat and sausages (Manassaram et al., 2006) manufacture of matches and special cement (ATSDR, 2001), etc, which makes exposure to nitrates inevitable. The global challenge of food shortage and the impoverishment of soil in many parts of the world make the use of fertilizers and other modern farming techniques ever more imperative. In the human body, nitrates induce oxidative damage through the release of nitrite and NO (Oladele et al., 1997). nitrates are also known to cause carcinogenic, mutagenic, teratogenic and embryotoxic effects (Kasyanenko et al.,1992). Vitamin $C$ and $E$ are known to be potent antioxidants (Ayo et al., 2006; Suteu et al. 2007), hence, it is conceivable that, their administration (in the form of vitamins C and E supplements) into the body may augment the function of endogenous free radical scavengers such as superoxide dismutase, catalase and glutathione peroxidase thereby decreasing the deleterious effects of nitrates and nitrites. The aim of the present study therefore was to investigate the effect of chronic exposure to nitrates

The solutions were kept at room temperature, and vitamin $\mathrm{E}$ was protected from direct contact with air on osmotic fragility and the possible ameliorative effect of antioxidant vitamins $C$ and $E$.

\section{MATERIALS AND METHODS}

Seventy (70) adult Wistar rats were used for the study. The animals were kept in large cages in the animal house for two weeks to acclimatise before commencement of the experiment. They were allowed free access to distilled water and fed pelletised growers feed (Vital Feed, Jos, Nigeria) before and during the experiment. Pelletised growers feed contains crude protein $(14.5 \%)$, fat $(7.0 \%)$, crude fibre $(7.2 \%)$, calcium $(0.8 \%)$, available phosphorus $(0.4 \%)$ (manufacturer's information leaflet). Drinking water was changed daily, and alternate day clearing and replacement of sawdust and droppings were carried out. Sodium nitrate salt (BDH Chemicals Limited, Poole, England) was dissolved in distilled water to make a stock solution containing $2.5 \mathrm{mg}$ $\mathrm{NaNO}_{3}$ in $0.1 \mathrm{ml}$ from which the animals were fed during the experiment. Tablets of Vitamin C (Em vitamin C, 100mg tabs. Emzor Pharmaceutical Industries, Lagos, Nigeria) were crushed into powder to prepare a solution containing $25 \mathrm{mg}$ of vitamin C in $0.1 \mathrm{ml}$. Similarly, capsules of vitamin E (Efishal $200^{\mathrm{TM}}$,Shalina Laboratories, Pvt, Mumbai, India) was cut open and emptied into a clean container. Vegetable oil was added to prepare a suspension containing $34 \mathrm{mg}$ of the vitamin $\mathrm{E}$ in $0.1 \mathrm{ml}$.

and sunlight to avoid degradation, by stocking in a dark, air-tight jar. Appropriate amounts of $\mathrm{NaNO}_{3}$ 
solution and the vitamins were collected using $1 \mathrm{ml}$ syringe for administration based on body weight of the animals.

The animals were randomly divided into seven groups of 10 rats each $(n=10)$. They were administered drugs or distilled water orally using a metallic canular between the $8.00 \mathrm{am}-10.00 \mathrm{am}$ daily for 60 days as follows: Group I (control) received distilled water; Group II - received $30 \mathrm{mg} / \mathrm{Kg}$ $\mathrm{NaNO}_{3}$; Group III - received $30 \mathrm{mg} / \mathrm{Kg} \mathrm{NaNO}{ }_{3}+500$ $\mathrm{mg} / \mathrm{Kg}$ vitamin C; Group IV - received $30 \mathrm{mg} / \mathrm{Kg}$ $\mathrm{NaNO}_{3}+750 \mathrm{mg} / \mathrm{Kg}$ vitamin C; Group V - received 30 $\mathrm{mg} / \mathrm{Kg} \mathrm{NaNO}{ }_{3}+300 \mathrm{mg} / \mathrm{Kg}$ vitamin E; Group VI received $30 \mathrm{mg} / \mathrm{Kg} \mathrm{NaNO} \mathrm{Na}_{3}+400 \mathrm{mg} / \mathrm{Kg}$ vitamin $\mathrm{E}$; Group VII - received $30 \mathrm{mg} / \mathrm{Kg} \mathrm{NaNO}+500 \mathrm{mg} / \mathrm{Kg}$ vitamin $\mathrm{C}+300 \mathrm{mg} / \mathrm{Kg}$ vitamin $\mathrm{E}$. The animals were weighed using a triple beam balance (Model OHAUS, 700 Series, Floram Park, N. J, U. S. A.) and values obtained were recorded at the beginning of the experiment and every two weeks. The doses of the drugs were adjusted according to the change in weights. At the termination of the experiment, the animals were anaesthetised by chloroform inhalation in a closed chamber and subsequently sacrificed. The thorax of the anaesthesized animal was cut open and with the aid of $5 \mathrm{ml}$ syringe with 21 Gauge needle, the pulsating heart of the rat was pierced and blood was aspirated. $3 \mathrm{ml}$ of blood from each rat was transferred into each EDTA bottle for the determination of osmotic fragility.

Sodium chloride stock solution was prepared and maintained at pH of 7.4 (Faulkner and King, 1970). Ten test tubes, each containing $5 \mathrm{ml}$ of the $\mathrm{NaCl}$ solution of concentrations ranging from 0.00 to $0.90 \%$ were arranged serially in a test tube rack and labelled according to the concentrations of the $\mathrm{NaCl}$. One set of the 10 test tubes was used to analyse each blood sample. $1 \mathrm{ml}$ syringe with 21 Gauge needle was used to transfer $0.02 \mathrm{ml}$ of blood (2 drops of $0.01 \mathrm{ml}$ ) from the EDTA bottle into each test tube of a set. Mixing was done immediately by gently inverting the test tube five times. The test tubes were allowed to stand for 30 minutes at room temperature $\left(26-28^{\circ} \mathrm{C}\right)$, after which the suspension was centrifuged at $2000 \mathrm{rpm}$ for 10 minutes using model IEC HN - SII centrifuge. The supernatant was transferred into a glass cuvette and the concentration of haemoglobin was measured at wavelength of 540nm using a spectrophotometer (Spectronic-20, Bausch and Lomb, U. S. A.) by reading the absorbance. The same procedure was repeated for each of the blood samples. The \% haemolysis was calculated using the formula of Faulkner and King (1970):

$$
\% \text { Haemolysis }=\frac{\text { Optical Density of Test Solution }}{\text { Optical Density of } S \tan \text { dard Solution }} \times 100
$$

The data obtained are expressed as mean \pm S. E. M. Differences in means of discrete parameters of any two groups were analysed using Student's $t$-test. Values of $p<0.05$ was considered significant.

\section{RESULTS}

Effect of sodium nitrate; Percent haemolysis in the blood of rats treated with $\mathrm{NaNO}_{3}$ was generally less than that of the control and the decrease was statistically significant at $0.60 \%$ and $0.50 \% \mathrm{NaCl}$ concentration. There was significant negative correlation between percent haemolysis and percent $\mathrm{NaCl}$ concentration in both the control $(r=-0.87, p<$ $0.001)$ and the nitrate-treated rats $(r=-0.94, p<$ 0.001 ); that is, as the percent $\mathrm{NaCl}$ concentration decreased, percent haemolysis increased in both groups

(Figure

1).

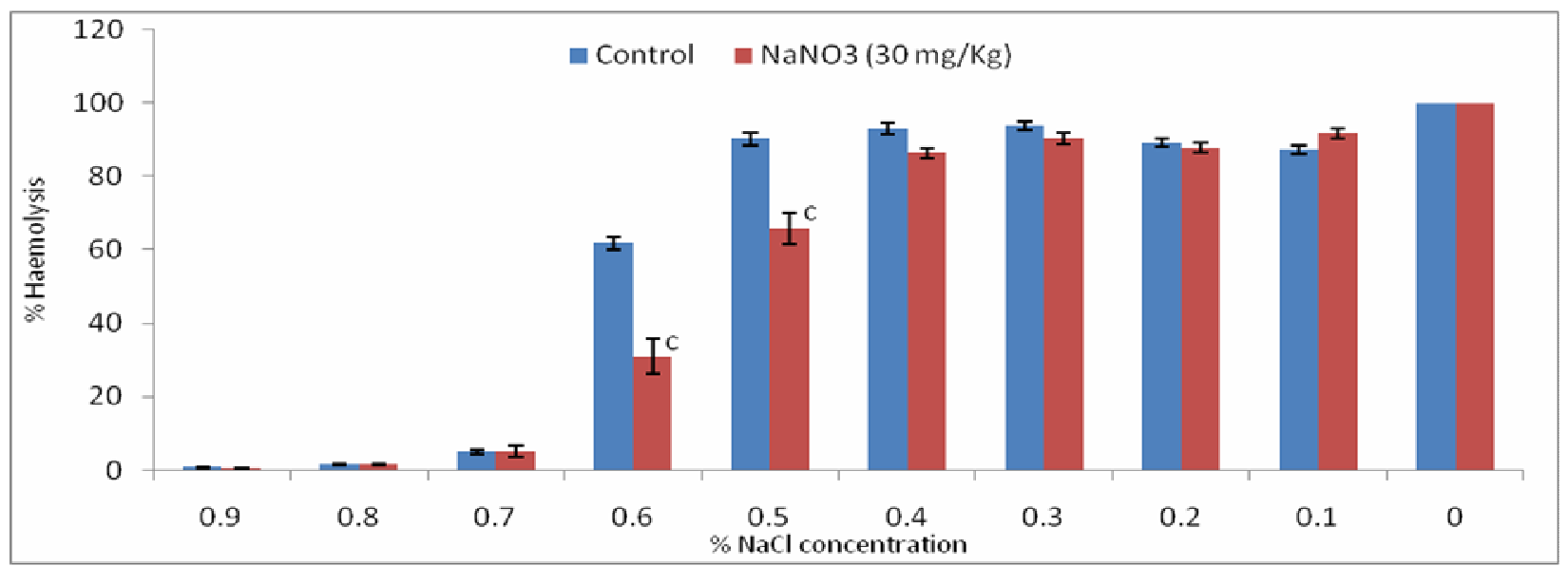

Figure 1: Percent haemolysis of control and nitrate-treated rats, ${ }^{c} p<0.05$ compared to control.

Effect of vitamin $\boldsymbol{C}$ administration: Percent haemolysis in the blood samples of rats given 750 $\mathrm{mg} / \mathrm{kg}$ vitamin C was significantly higher than in nitrate-treated rats at $0.70 \%$ and $0.60 \% \mathrm{NaCl}$ concentration. Haemolysis was similar in rats treated with $\mathrm{NaNO}_{3}+750 \mathrm{mg} / \mathrm{kg}$ vitamin $\mathrm{C}$ and those treated with $\mathrm{NaNO}_{3}$, at all other concentrations with maximum haemolysis occurring at $0.10 \% \mathrm{NaNO}_{3}$ concentration for both groups (Figure 2). 
Bajopas Volume 4 Number 1 June, 2011

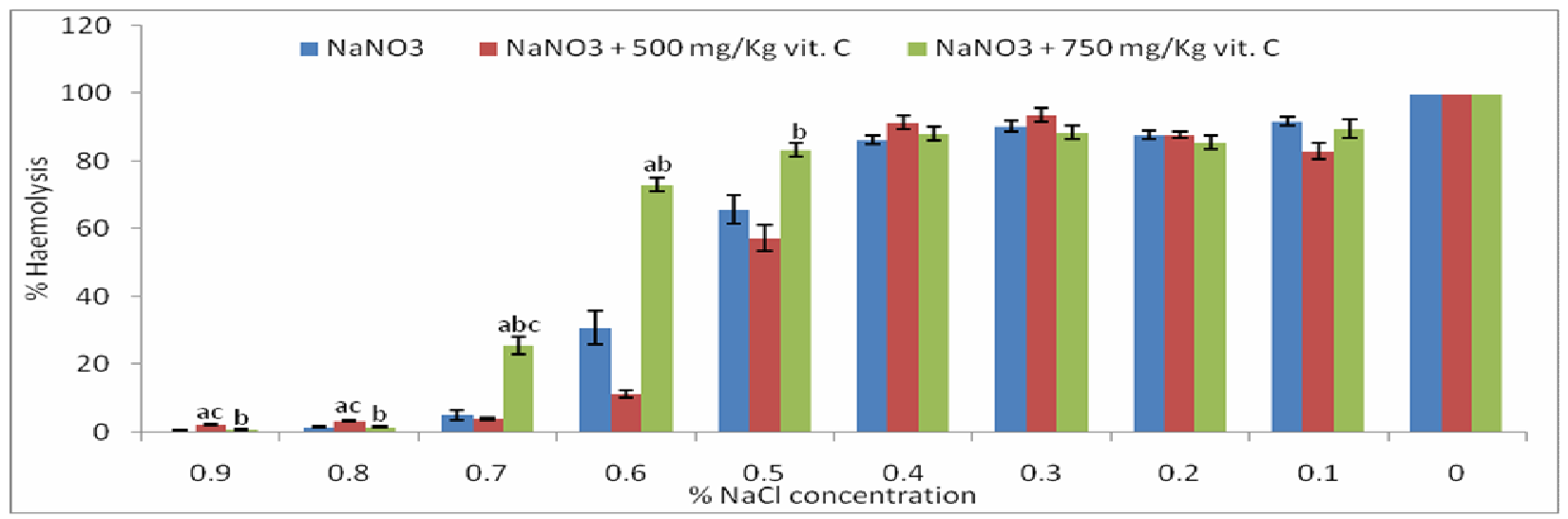

Figure 2: Percent haemolysis of nitrate- and vitamin C-treated rats.

${ }^{a} \mathrm{p}<0.05$ compared to $\mathrm{NaNO}_{3}$-treated rats, ${ }^{\mathrm{b}} \mathrm{p}<0.05$ compared with $\mathrm{NaNO}_{3}+500 \mathrm{mg} / \mathrm{kg}$ vit. C-treated rats.

${ }^{c} \mathrm{p}<0.05$ compared to control.

Effect of vitamin $E$ administration: Percent haemolysis was higher at all $\mathrm{NaCl}$ concentrations in blood collected from rats treated with $300 \mathrm{mg} / \mathrm{kg}$ vitamin $\mathrm{E}$ when compared with the nitrate-treated rats, and the difference was statistically significant between $0.90 \%$ and $0.50 \% \mathrm{NaCl}$ concentration. Maximum haemolysis was slightly higher in rats treated with $300 \mathrm{mg} / \mathrm{kg}$ vitamin E (92.37 \pm 3.9$)$ when compared with the nitrate-treated ones $(91.76 \pm 2.5)$, and it occurred at a higher $\mathrm{NaCl}$ concentration of $0.40 \%$ in the vitamin E-treated rats and $0.10 \%$ in the nitrate-treated. Percent haemolysis in rats treated with $\mathrm{NaNO}_{3}+300 \mathrm{mg} / \mathrm{kg}$ vitamin E was statistically similar to that of control between $0.60 \%-0.10 \% \mathrm{NaCl}$ concentration.

Percent haemolysis was higher at all $\% \mathrm{NaCl}$ concentrations in the blood collected from rats treated with $400 \mathrm{mg} / \mathrm{kg}$ vitamin $\mathrm{E}$ and the difference was statistically significant at $0.06 \%$ and $0.50 \% \mathrm{NaCl}$ when compared with the nitrate-treated rats. Maximum haemolysis in the rats treated with $400 \mathrm{mg} / \mathrm{kg}$ vitamin $\mathrm{E}$ was $99.42 \pm 7.1 \%$ at $0.40 \% \mathrm{NaCl}$ concentration, and $91.76 \pm 2.5 \%$ at $0.1 \% \mathrm{NaCl}$ concentration in the nitrate-treated rats. Percent haemolysis of rats treated with $\mathrm{NaNO}_{3}+400 \mathrm{mg} / \mathrm{kg}$ vitamin $\mathrm{E}$ was statistically the same as that of the control at all the $\mathrm{NaCl}$ concentrations. Generally, there was no statistically significant difference in percent haemolysis obtained in rats treated with the two different doses of vitamin $\mathrm{E}$, except at $0.70 \% \mathrm{NaCl}$ concentration, when the percent haemolysis in rats treated with the lower dose was markedly higher than in those rats treated with the higher dose.

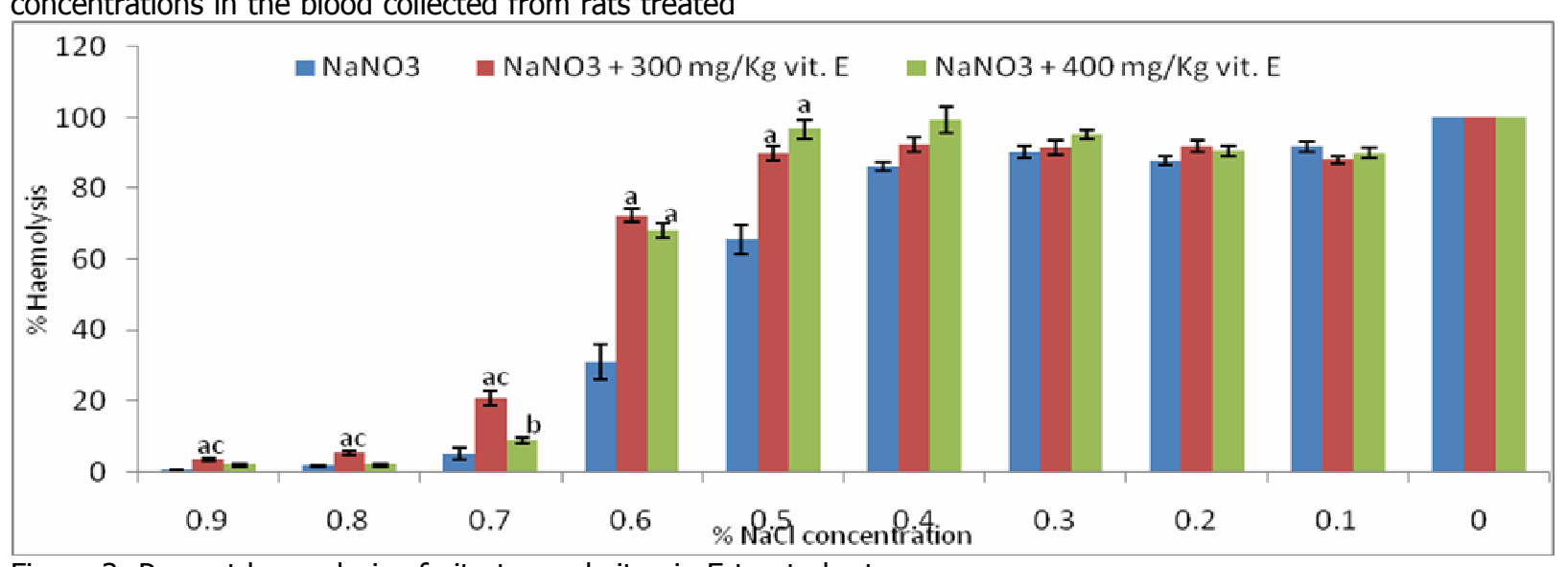

Figure 3: Percent haemolysis of nitrate- and vitamin E-treated rats.

${ }^{a} \mathrm{p}<0.05$ compared to $\mathrm{NaNO}_{3}$-treated, ${ }^{\mathrm{b}} \mathrm{p}<0.05$ compared to $\mathrm{NaNO}_{3}+300 \mathrm{mg} / \mathrm{kg}$ vit. E-treated.

${ }^{c} \mathrm{p}<0.05$ compared to control.

Effects of vitamin $C$ and $E$ co-administration: Percent haemolysis in the blood collected from rats co-administered vitamins $\mathrm{C}+\mathrm{E}$ was higher in most of $\mathrm{NaCl}$ concentrations when compared with $\mathrm{NaNO}_{3}-$ treated, and the difference was statistically significant between $0.90 \%$ and $0.40 \% \mathrm{NaCl}$ concentration. Maximum haemolysis was $95.41 \pm 2,7 \%$ at $0.40 \%$
$\mathrm{NaCl}$ concentration for rats treated with vitamin $\mathrm{C}+\mathrm{E}$, and $91.76 \pm 2.5 \%$ at $0.10 \% \mathrm{NaCl}$ concentration for the nitrate-treated rats. Besides, co-administration of both vitamins also produced marked increase in percent haemolysis as compared to control at $\mathrm{NaCl}$ concentrations between 0.90 and $0.60 \%$. 


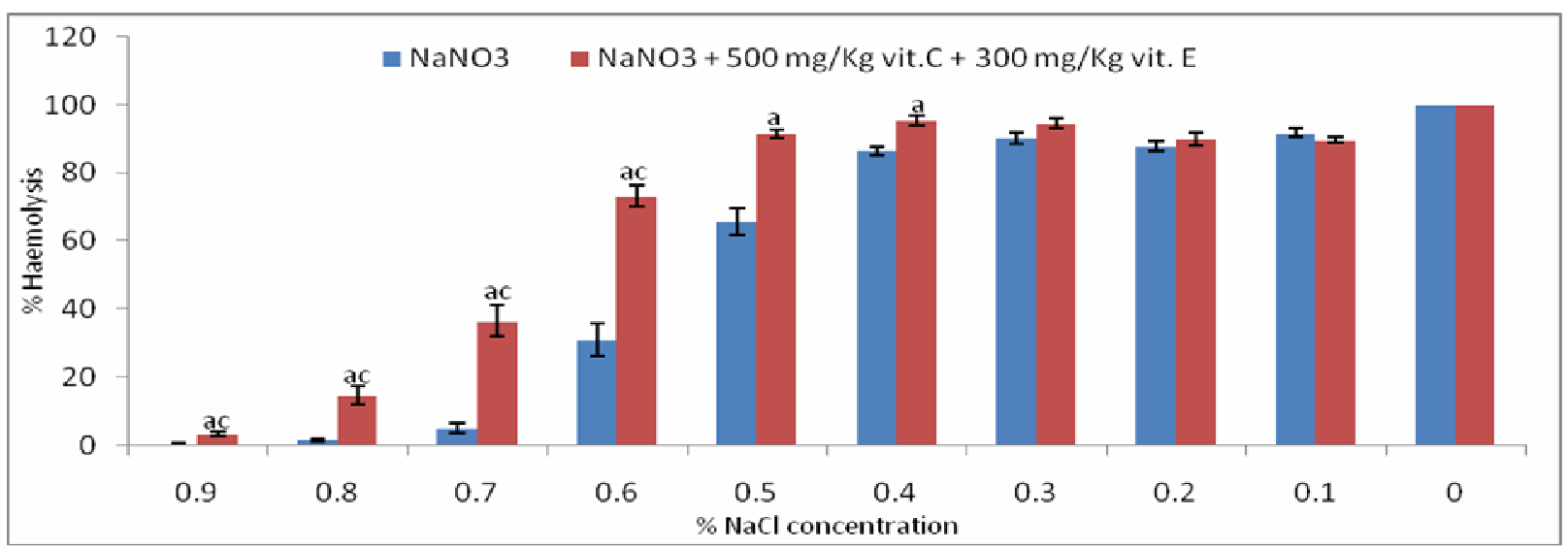

Figure 4: Percent haemolysis of nitrate- and vitamin $\mathrm{C}+\mathrm{E}$-treated rats.

a $\mathrm{p}<0.05$ compared to $\mathrm{NaNO}_{3}$-treated, ${ }^{\mathrm{c}} \mathrm{p}<0.05$ compared to control.

\section{DISCUSSIONS}

Chronic administration of sodium nitrate decreased the percent haemolysis, that is, it decreased osmotic fragility of erythrocytes of the exposed rats (figure 1). This result contradicted the previous findings that nitrates, through oxidative process change membrane structural state by decreasing membrane fluidity provoking haemolysis (Batina, 1998). Oxidative injury to erythrocyte membrane was reported to cause formation of pyknocytes (Fischer et al., 1985; Bensoltane et al., 2006) - shrunken and condensed cells - which result in increased ability to resist osmotic stress. A recent study by Bensoltane et al. (2006) reported that rats subjected to sub-chronic nitrate effect developed capacities of adaptation. A similar finding of adaptation was reported in sheep (Sinclair and Jones, 1964). Thus, the decrease in osmotic fragility of erythrocytes after chronic exposure to sodium nitrate poisoning in the present study may be due to the ability of the erythrocytes to develop adaptive compensatory changes via homeostatic mechanisms to reduce the toxicity.

Administration of $750 \mathrm{mg} / \mathrm{kg}$ vitamin C to $\mathrm{NaNO}_{3}$-treated rats increased erythrocyte osmotic fragility of $\mathrm{NaNO}_{3}$-treated rats to values statistically similar to that of control (reversed the $\mathrm{NaNO}_{3}$ effect) (Figure 2). This shows the ameliorative effect of the vitamin at that dose. This effect was apparently due to the ability of the vitamin to strengthen the physical integrity of erythrocyte membrane (Awodi et al., 2005) and through free radical quenching activity (Gecha and Fagan, 1992). Thus, vitamin C may be of benefit during chronic nitrate exposure.

There was significantly higher percent haemolysis at $0.90 \%$ and $0.80 \% \mathrm{NaCl}$ concentration in blood samples collected from rats treated with 500 $\mathrm{mg} / \mathrm{kg}$ vitamin $\mathrm{C}$ when compared with nitrate-treated ones (Figure 2). Furthermore, maximum haemolysis was higher in the blood of rats given $500 \mathrm{mg} / \mathrm{kg}$ vitamin C (93.59 \pm 3.8) when compared with the $\mathrm{NaNO}_{3}$-treated rats $(91.76 \pm 2.5)$, and it occurred at a higher $\mathrm{NaCl}$ concentration of $0.30 \%$ and $0.10 \%$ successively. Percent haemolysis of erythrocytes of rats treated with $750 \mathrm{mg} / \mathrm{kg}$ vitamin $\mathrm{C}$ was generally higher than those of the $\mathrm{NaNO}_{3}$-treated and the
$\mathrm{NaNO}_{3}+500 \mathrm{mg} / \mathrm{kg}$ vitamin C-treated rats at concentrations between 0.90 and 0.5 . $\% \mathrm{NaCl}$ and was statistically similar to that of the control. This shows the dose-dependant effect of vitamin $C$ in chronic nitrate toxicity and agrees with previous findings that the effect of vitamin $C$ in oxidative stress-related toxicity increases with an increase in dose (Ambali et al., 2007).

Vitamin $\mathrm{E}$ at both doses increased the osmotic fragility of the nitrate-treated rats back to normal especially the dose of $400 \mathrm{mg} / \mathrm{kg}$ (Figure 3), indicating that the vitamin counteracted the effect of $\mathrm{NaNO}_{3}$ on osmotic fragility. This demonstrates the ameliorative effect of vitamin $\mathrm{E}$, which is known to be a potent antioxidant (Ayo and Oladele, 1996; Whitehead and Keller, 2002). Erythrocyte osmotic fragility of rats treated with the two doses of the vitamin was statistically similar as shown in Figure 3, thus revealing no dose-dependant effect. However, a different dose margin may show a different result.

Co-administration of vitamins $\mathrm{C}$ and $\mathrm{E}$ significantly increased the osmotic fragility of $\mathrm{NaNO}_{3}-$ treated rats to a level higher than that of control (Figure 1 and 4). This effect is detrimental to the health of the animals as it predisposes them to anaemia. Further studies on the effect of coadministration of these vitamins to normal rats on osmotic fragility may require further clarification. The above result also demonstrated the synergistic effect of the two vitamins as reported by Khmelevsky and Poberezkina (1990). However, the synergistic effect seen in the present study is negative in nature. This is contrary to the findings of of Appenroth et al. (1997); Altuntas et al. (2002); Gokalp (2003); Khadkhodaee et al. (2005) and Suteu et al. (2007), who showed the protective effects of vitamins $C$ and $E$ in chronic toxicity associated with oxidative stress induced by different chemicals. Worthy of note is the fact that different mechanisms of action have been reported for both nitrates (Dutsheyko, 1989; Antipina et al.,1990; Donavan, 1990; Sidoryak and Minyaylenko, 1991; Zadorozhnaya, 1991; Kasyanenko et al.,1992; Karpovsky et al.,1994; IPCS, 1999; ATSDR, 2001) as well as vitamins C (Gecha and Fagan, 1992; Williams, 1997; Proteggente et al., 2001; Singhal et al., 2001; 
Whitehead and Keller, 2002; Balz, 2003; Guan et al., 2004; Son et al., 2004; Awodi et al., 2005) and E (Boadi; 1991; Packer, 1991; Javouhey-Donzel et al., 1993; Gulthrie and Picciano, 1995; Karlson, 1997; Azzi and Stocker, 2000; Jain et al., 2000; Sushil et al., 2000; Droge et al., 2006). This suggests that the interaction of these substances in vivo will be complex and is likely to result into a wide range of effects. The nature of the administered chemical, the dose, duration, as well as the route of administration in the present study, which may allow interaction between $\mathrm{NaNO}_{3}$ and the vitamins in the rats' stomach before absorption, may explain the observed effects.

The doses of $500 \mathrm{mg} / \mathrm{kg}$ vitamin $\mathrm{C}$ and $300 \mathrm{mg} / \mathrm{kg}$ vitamin $\mathrm{E}$ showed similar effects on osmotic fragility when administered to $\mathrm{NaNO}_{3}$-treated rats except for concentrations of $0.70,0.60$ and 0.50 $\% \mathrm{NaCl}$ where vitamin $\mathrm{E}$ markedly increased osmotic fragility more than vitamin $C$ (Figure 2 and 3). This indicates that vitamin $\mathrm{E}$, which is lipid-soluble, has more potent antioxidant activity than vitamin C, thus agreeing with previous reports (Tsuchihashi et al., 1995; Ocak et al., 2007). Both vitamins at higher doses improved erythrocyte osmotic fragility to normal values where they produced similar effects except for $0.70 \% \mathrm{NaCl}$ concentration where vitamin $\mathrm{E}$ showed similar effect to control while vitamin C significantly increased osmotic fragility more than control and vitamin E-treated groups (Figure 2 and 3 ). This indicates the ameliorative effect in chronic nitrate

\section{REFERENCES}

Altuntas, I., Delibas, N. and Suteu, R. (2002). The effects of organophpsphate insecticide methidathione onlipid peroxidation and antioxidant enzymes in rats erythrocytes: Role of vitamins $\mathrm{E}$ and $\mathrm{C}$. Human and Experimental Toxicology. 21: 681685.

Ambali, S., Akanbi, D., Igbokwe, N., Shittu, M., Kawu, M. and Ayo, J. (2007). Evaluation of subchronic chlorpyrifos poisoning on haematological and serum biochemical changes in mice and protective effect of vitamin C. The Journal of Toxicological Sciences. 32 (2): 111-120.

Antipina, V. D., Falunina, Z.P. and Moiseyev, Y. V. (1990). The Nitrate Problem and Methods of its Resolution. Moscow, pp. 431.

Appenroth, D., Frob, S., Kersten, L., Splinter, S. K., Winnefeld, K. (1997). Protective effects of vitamin $\mathrm{E}$ and $\mathrm{C}$ on cisplatin nephrotoxicity in developing rats. Archives of Toxicology. 71(11): 677-683.

ATSDR (Agency for Toxic Substances and Disease Registry) (2001). Case Studies in Environmental Medicine: Nitrate/nitrite toxicity. Department of Health and Human Services, Wigington, P. S.(Ed), DTEM, U.S.A., 22 pp.

Ayo, J. O., Minka, N. S. And Mamman, M. (2006). Excitability scores of goats administered ascorbic acid and transported during hot-dry conditions. Journal of Veterinary Science. 7(2):127-131.

Ayo, J. O. and Oladele, S. B. (1996). Natural anti-oxdiants and their potential uses in prophylaxis and therapy of disease conditions. West African Journal of Pharmacology and Drug Research. 12: $69-76$.

Awodi, S., Ayo, J.O., Nwude, C.I. and Dzenda, T.(2005). Effects of sodium nitrite and ascorbic acid on the poisoning, with vitamin $\mathrm{E}(400 \mathrm{mg} / \mathrm{kg}$ ) having a better effect. This is in agreement with the previous findings (Ayo and Oladele, 1996; Awodi et. al., 2005).

The increase in osmotic fragility observed in rats treated with the lower doses of both vitamins $\mathrm{C}$ and $\mathrm{E}$ was ameliorative more than the combination of both vitamins which showed higher erythrocyte osmotic fragility than the control group (Figures 2 and 3). However, the increase in erythrocyte osmotic fragility observed in the vitamins $\mathrm{C}+\mathrm{E}$ - co-administered rats (Figure 4) is detrimental due to the risk of anaemia. This finding, again, indicates synergism between the vitamins in agreement with other findings (Hanafy and Sultan, 2004; Ocak et al, 2007; Suteu et al., 2007). Hence, concurrent oral intake of these vitamins should be avoided by individuals with long-term exposure to nitrates.

\section{Conclusions}

Based on the results obtained in this study, it was concluded that, sodium nitrate caused significant toxicity by decreasing erythrocyte osmotic fragility of the treated rats. Separate administration of both vitamin $\mathrm{C}$ and $\mathrm{E}$ ameliorated sodium nitrate toxicity by increasing erythrocyte osmotic fragility back to normal in a dose dependant manner, with vitamin $E$ producing the better effect. However, coadministration of the two vitamins increased osmotic fragility to values significantly above the normal which is detrimental to the rats due to the risk of anaemia.

erythrocyte osmotic fragility in Red Sokoto Goats. Proceedings of 10th Annual Conference, Annual Science Association of Nigeria (ASAN), University of Ado-Ekiti, Nigeria. Pp. $65-68$.

Azzi, A. and Stocker, A. (2000). Vitamin E: Nonantioxidant roles. Progress in Lipid Research. 39: $231-255$.

Balz, F. (2003). Vitamin C intake. Nutritional Disease. 14: $1-18$.

Batina, P. (1988). Aspects meteaboliques et toxicologiques de lerythrocyte chez le rat traite aux nitrates et nitrites. These de Doctorat. Universite de Poul Sabatier, Toulouse, France, 210 $\mathrm{pp}$.

Boadi, W.Y. (1991). Effects of dietary supplementation with vitamin $E$, riboflavin and selenium on central nervous system oxygen toxicity. Pharmacology and Toxicology. 68: $77-82$.

Bensoltane, S., Messerer, L., Yuobi, M., Berrebbah, H., Djekoun, M. and Djebar, M. R., (2006). Effects of acute and sub-chronic ammonium nitrate exposure on rat liver and blood tissues. African Journal of Biotecnology. 5(9): 749-754.

Donovan, J.W. (1990): Nitrates, nitrites and other sources of methaemoglonaemia. In: Haddad, $B$. and Winchester, E. C. (Eds) Clinical management of poisoning and drug overdose. WB Sauders, Philadelphia, Pp. $1419-1431$.

Droge, W., Kinscherf, R., Hildebrandt, W.and Schmitt, J. (2006). The deficit in low molecular weight thiols as a target for anti-aging therapy. Current Drug Targets. 7 (11): $1505-1512$.

Dusheyko, A. A. (1989). Vitamin A - Metabolism and Function. Naukova Dumka, Kiev, 288 pp. 
Fischer, T. M., Meloni, T., Pescamona, G. P. and Arese, P. (1985). Membrane cross bonding in red cells in favic crisis: A missing link in the mechanism of extravascular haemolysis. British Journal of Haematology. 59: 159-169.

Faulkner, W.R. and King, J.W. (1970). Manual of Clinical Laboratory Procedures. Chemical Rubber Company, Cleveland, Ohio, U. S. A., 345 pp.

Gecha, O.M. and Fagan, J. M.(1992). Protective effect of ascorbic acid on the breakdown of proteins exposed to hydrogen peroxide in chicken skeletal muscle. Journal of Nutrition. 12: 2089 - 2093.

Gokalp, O. (2003). The effects of methidathion on liver: roles of vitamins $\mathrm{C}$ and $\mathrm{E}$. Toxicology and Industrial health. 19(2-6): 63-67.

Guan, Z., Lui, C. Y., Morkin, E. And Bahl, J. J. (2004). Oxidative stress and apoptosis in cardiomyocyte induced by high-dose alcohol. Journal of Cardiovascular Pharmacology. 44(6):696-702.

Guthrie, H. A. And Picciano, M. F. (1995). Fat Soluble Vitamins in Human Nutrition, Mosby Company, New York, 420 pp.

Hanafy, S. And Soltan, M. E. (2004): Effects of vitamin E pretreatment on subacute toxicity of mixture of $\mathrm{Co}, \mathrm{Pb}$ and $\mathrm{Hg}$ on nitrate-induced nephrotoxicity in rats. Environmental Toxicology and Pharmacology. 17 (3): $159-167$.

IPCS (International Programme on Chemical Safety) (1999). Nitrates and nitrites. Poisons, Information Monograph (Group Monograph) GO 16, Chemical. Ruse M. (Ed.), 35 pp.

Jain, S., McVie, R. and Smith, T. (2000). Vitamin E supplementation restores glutathione and malondialdehyde to normal concentrations in erythrocytes of type I diabetic children. Diabetes Care. 23: $1389-1395$.

Javouhey-Donzel, A., Guenot, L. And Maupoil, V. (1993). Rat vitamin $\mathrm{E}$ status and heart lipid peroxidation, effect of dietary oxylinoleic acid and morine n-3 Fatty Acids. Lipids. 28: 651-655.

Karlson, J. (1997): Antioxidants and exercise. In: Principles of Radical formation, King, S. (ed), Saunders, Boston, Pp. $96-101$.

Khadkhodaee, M., Khastar, H., Faghihi, M., Ghaznavi, R. and Zahmatkesh, M. (2007). Effects of cosupplimentation of vitamin $C$ and $E$ on gentamicininduced nephrotoxicity in rats. Experimental Physiology. 90: 571-576.

Karpovsky, V.I. (1994). Metabolic pathology following chronic nitrate poisoning of cattle and its prophylactic methods. Author's Comprehensive Summary of Doctor of Philosophy Thesis Ukrainian State Agricultural University, Kiev, 16 pp.

Kasyanenko, I. V., Pinchuk, V. G. Mysasoyedov, D.V., Pivnyuk, V. M. and Osipova, L. A. (1992). Oncology. Naukova Dumka, Kiev, 264 pp.

Khmelevsky, U. V. and Poberezkina, N. B. (1990). Vitamins and the Age of Man. Naukova Dumka, Kiev, 164 pp.

Manassaram, D. M., Backer, L. C. and Moll, D. M. (2006). A review of nitrates in drinking water: Maternal exposure and adverse reproductive and developmental outcomes. Environmental Health Perspective. 114 (3): 320 - 327.

Ocak, S., Gorur, S., Hakverdi, S.,Celik, S. and Erdogan, S., (2007). Protective effect of cafeic acid phenethyl esther, vitamin C, vitamin E and acetylcystein on vancomycin-induced nephrotoxicity in rats. Basic and Clinical Pharmacology and Toxicology, 100(5): 328-333.

Oladele, S. B., Ayo, J. O. and Adaudi, A. O. (1997). The emergence of nitrate and nitrite poisoning in humans and domestic animals. West African Journal of Pharmacology and Drug Research. 13: $50-58$.

Packer, L. (1991). Protective role of vitamin E in biological systems. American_Journal of Clinical Nutrition. 53: 1050S - 1055S.

Proteggente, A. R., England, T.G., Rice-Evans, C.A., and Halliwell, B. (2001). Iron supplementation and oxidative damage to DNA in healthy individuals with high plasma ascorbate. Biochemical and Biophysical Research Communications. 288: 24 251.

Sidoryak, N. G. and Minyaylenko, T. D. (1991). Effect of prolonged administration of sodium nitrite on oxygen transport function and acid-base status of the blood._Pharmacology and Toxicology. 3: 88 92.

Sinclair, K. B. and Jones, D. I. H. (1964). Nitrate toxicity in sheep. Journal of Science of Food and Agriculture. 15(10): 717-721.

Singhal, S., Gupta, R. and Gogle, A. (2001). Comparison of antioxidant efficacy of vitamin $E$, vitamin $C$, vitamin $\mathrm{A}$ and fruits in coronary heart diseases. A controlled trial. Journal of the Association of Physicians, India. 49: 327 - 331

Son, E. W., Mo,S. J., Rhee, D. K. and Pyo, S. (2004). Vitamin C blocks TNF-alpha-induced NF-kappa B activation and ICAM-1 Expression in human neuroblastoma cells. Archives of Pharmacology Research. 27(10):1073-1079.

Sushil, K. J., Robert, M. V. and Tiney, S. (2000). Vitamin $\mathrm{E}$ supplimentation restores glutathione and malonedialdehyde to normal concentrations in erythrocytes of type I diabetic children. Journal of Diabetic Children. Diabetes Care. 23(9): 1389 1394.

Suteu, R., Altuntas, I., Buyukvanli, B., Akturk, O., Koylu, H. and Delibas, N. (2007). The effects of diazozin on lipid peroxidation and antioxidant enzymes in rats erythrocytes: role of vitamins $\mathrm{E}$ and $\mathrm{C}$. Toxicology and Industrial Health. 23(1): 13 - 17.

Tsuchuhashi, H., Kigoshi, M., Iwatsuki, M. and Niki, E. (1995). Action of $\beta$-carotene as an antioxidant against lipid peroxidation. Archives of Biochemistry and Biophysics. 323 (1): $137-147$.

Whitehead, C. C.and Keller, T. (2003). An update on ascorbic acid in poultry. World's Poultry Science Journal. 59: 161 - 184.

Williams, S. R., (1997). Recommended daily allowance. In: Nutrition and Diet Therapy, 8th edition, Mosby, St. Louis, Philadelphia, 243 pp.

Wogan, G. N., Generoso, W., Koller, L. D. and Smith, R.P. (1995). Nitrate and Nitrite in Drinking Water: National Academic Press, Washington, D.C., 73 pp.

Zadorozhnaya, G. P. (1991). Methods of decreasing nitrate and nitrite value in livestock products. Ukrainian Research Institute of Science and Technical Information of the State Plan. Kiev, 44 pp. 